\title{
Potensi Penerapan Konsep Produksi Bersih pada Industri Keramik di Probolinggo
}

\section{Potensial Implementation of Cleaner Production Concept for Ceramic Industries in Probolinggo}

\author{
LESTARIO WIDODO \\ Pusat Teknologi Lingkungan, Badan Pengkajian dan Penerapan Teknologi \\ Gedung Geostech 820 Puspiptek Serpong Tangerang Selatan \\ lestario.widodo@bppt.go.id
}

\begin{abstract}
The industrial sector is a very strategic sector to be relied upon in support of economic growth. However, on the other hand, this sector contributes significantly to the problems of environmental degradation and natural resource degradation. To prevent the occurrence of wasteful and inefficient use of natural resources and reduce the potential for environmental impacts, the industry in its operation needs to apply the concept of clean production. The city of Probolinggo has many ceramic industries that are still not efficient in using resources in its production process. Therefore, the research on the application of the Cleaner Production Concept in the Probolinggo City ceramics industry is implemented with the aim of identifying non-product outputs or NPOs, handling NPOs and providing priority recommendations for handling NPOs in order to increase production efficiency, Decreased pollution levels and decreased production costs. Given that the ceramics industry is an energy-based industry, the efforts to increase the combustion temperature to reduce unspecified products will have an impact on the reduction of waste. In addition, the replacement of ordinary lamps with energy saving lamps and installation of electric meters (measuring devices of electricity consumption) on each production equipment can provide information for management in making decisions related to savings. Based on the empirical data, the potential savings that can be made by applying the concept of net production is between $10 \%$ and $30 \%$ of production costs.
\end{abstract}

Keyword :Cleaner Production, Non Product Output,Sustainable Resource Management

\begin{abstract}
ABSTRAK
Sektor industri merupakan sektor yang sangat strategis untuk diandalkan dalam mendukung pertumbuhan ekonomi. Walaupun demikian dalam sisi lainsektor ini memberikan kontribusi yang cukup signifikan terhadap permasalahan degradasi lingkungan dan penurunan sumberdaya alam (SDA). Untuk mencegah terjadinya pemanfaan SDA yang boros dan tidak efisien serta mengurangipotensi dampak lingkungan maka industridalam pengoperasiannyaperlu menerapkankonsep produksi bersih (clean production). Kota Probolinggo memiliki banyak industri keramik yang masih belum efisien dalam menggunakan sumber daya dalam proses produksinya. Oleh karena itu, penelitian tentang penerapan konsep Produksi Bersih di industri keramik Kota Probolinggo ini dilaksanakan dengan tujuan untukmengidentifikasikan jenis keluaran yang nonproduk atau Non Product Output(NPO), upaya penanganan NPO dan memberikan rekomendasi prioritas penanganan NPO tersebut dalam upaya peningkatan efisiensi produksi, penurunan tingkat pencemaran serta penurunan biaya produksi.Mengingat industri keramik merupakan industri yang berbasis pada penggunaan energi (energy intensive based industry) maka upaya peningkatan suhu pembakaran untuk mengurangi produk yang tidak sesuai (unspecification products)akan memberikan dampak pada penurunan limbah yang keluar.Selain itu,penggantian lampu biasa dengan lampu hemat energisertapemasangan meteran listrik (alat ukur konsumsi listrik) pada setiap peralatan produksi dapat memberikan informasi bagi manajemen dalam mengambil keputusan terkait dengan penghematan.Berdasarkan data empiris, potensi penghematan yang dapat dilakukan dengan penerapan konsep produksi bersih ini berkisar antara 10\% dan $30 \%$ dari biaya produksi.
\end{abstract}

Kata Kunci: Produksi Bersih, Non Product Output,Sustainable Resource Management 


\section{PENDAHULUAN}

\subsection{Latar Belakang}

Sektor industri merupakan sektor strategis yang dapat diandalkan untuk mendukung pertumbuhan ekonomi baik secara nasional maupun regional. Namun demikian, sektor industri juga memberikan kontribusi yang cukup signifikan terhadap permasalahan lingkungan dan sumberdaya alam (SDA). Pertumbuhan ekonomi dengan memanfaatkan SDA dibarengi dengan meningkatnya kondisi sosial sering memberikan dampak kerusakan pada lingkungan yang meningkat pula. Untuk mengurangi permasalahan tersebut maka manajemen pemanfaatan SDA harus mempertimbangkan keberlajutannya (sustainable resource management).

Sebagai negara berkembang yang tengah memacu pertumbuhan ekonomi, Indonesia masih mengandalkan sumber daya alam yang penggunaannya masih belum efisien karena umumnya masih menggunakan peralatan berteknologi kurang efisien dan kurang bersih sehingga masih berpotensi menimbulkan limbah yang mencemari lingkungan hidup sekitar.

Untuk mengatasi hal ini, Indonesia perlu menerapkan Konsep Ekonomi Hijau (Green Economy) yang bertujuan meningkatkan efisiensi pemanfaatan sumber daya, pemberantasan kemiskinan dan penciptaan lapangan kerja yang layak, serta memastikan pertumbuhan ekonomi yang berkelanjutan ${ }^{(1)}$.

Konsep produksi bersih merupakan salah satu strategi pengelolaan lingkungan yang bersifat preventif dan terpadu yang perlu diterapkan secara terus menerus pada proses produksi dan daur hidup produk dengan tujuan untuk mengurangi resiko terhadap manusia dan lingkungan. ${ }^{(2)} \mathrm{Di}$ Indonesia, landasan Hukum Pelaksanaan Produksi Bersih adalah UU RI No. 32 Tabun 2009 tentang Perlindungan dan Pengelolaan Lingkungan Hidup ${ }^{(3)}$.

Sejak tahun 1980-an kajian tentang teknologi yang ramah lingkungan menjadi prioritas. Prinsip utama konsep ini adalah mencegah terjadinya polusi (pollution prevention) dengan menggunakan proses produksi yang lebih bersih (cleaner production) atau mengintegrasikan prinsip ekologi dalam proses (eco-efficiency) ${ }^{(4)}$. Produksi bersih ini merupakan generasi kedua perkembangan teknologi lingkungan. Dalam produksi lebih bersih, langkah praktisnya adalah bagaimana suatu proses dapat :

a. mengurangi pemakaian energi dan bahan mentah produksi;

b. mengurangi limbah yang dihasilkan; dan c. memperbesar potensi pendaurulangan bahan mentah produksi dan produk samping (by-product) ${ }^{(5)}$.

Ada berbagai cara untuk menerapkan langkahlangkah peningkatan efisiensi untuk proses, produk dan layanan dalam kegiatan industri. Cara penerapan produksi bersih harus melalui suatu metodologi tertentu untuk mencapai tujuan dari produksi bersih itu. Dalam pelaksanaannya di lapangan metodologi tersebut dilengkapi dengan pedoman teknis. Pemilihan teknologi merupakan usaha pertama yang harus ditetapkan berdasarkan kesesuaian dengan kondisi dan kemudahan untuk dipraktekkan di Indonesia. Pendekatan yang digunakan dalam penerapan Teknologi Produksi Bersih yaitu dengan cara sebagai berikut ${ }^{(6)}$ :

- melakukan tata kelola yang baik (Good House Keeping, GHK) terhadap peralatan teknologinya; dan.

- melakukan pengelolaan yang baik terhadap bahan kimia dan bahan baku lainnya (Chemical Management, CM)

Usaha dalam produksi bersih iniyaitu memfokuskan pada manajemen peningkatan produktivitas, penghematan biaya, pengurangan dampak lingkungan dan perbaikan prosedur organisasi serta peningkatan keselamatan di tempat kerja.Secara lebih teknis yaitu memfokuskan pada penerapan langkah-langkah fisikproduksi hijau yang merupakan gabungan antara dua konsep Produksi Bersih dan Efisiensi Energi.

Perspektif ekonomi menjadi kunci utama atas penerapan Produksi Bersih, oleh karena itu dalam pengambilan keputusan upaya perbaikan dijelaskan pula metodologi ekonomi yaitu analisa biaya keuntungan (CBA, Cost Benefit Analysis)' untuk Produksi Bersih dan Akuntansi Manajemen Lingkungan (EMA, Environmental Management Accounting). Perspektif ekonomi ini menunjukkan cara objektif untuk mengetahui dampak finansial terhadap kinerja lingkungan di industri secara fisik dan moneter ${ }^{(7)}$.

Dampak finansial dalam pengambilan keputusan yang berhubungan dengan isu-isu lingkungan, seringkali salah dalam perhitungannya akibat adanya biaya yang tidak terlihat (hidden cost) maupun overhead cost apabila menggunakan metode perhitungan akuntansi konvensional. Untuk dapat melihat secara lebih jelas lingkup biaya lingkungan, maka telah dikembangkan Environmental Management Accounting (EMA) $)^{(7)}$ sebagai perangkat untuk membantu para pelaku usaha dalam meningkatkan performa finansial sekaligus kinerja lingkungannya. Secara sistematis, EMA mengintegrasikan aspek 
lingkungan dari perusahaan ke dalam akuntasi manajemen dan proses pengambilan keputusan. Selanjutnya EMA membantu pelaku usaha untuk mengumpulkan, menganalisa dan menghubungkan antara aspek lingkungan dengan informasi moneter maupun fisik.

Kota Probolinggo merupakan daerah yang berkembang dan mengembangkan onfarm industri kecil paska pertanian (agro). Data Dinas Koperasi, Energi Mineral, Industri dan Perdagangan (Diskoperindag) menunjukkan bahwa pada tahun 2014 profil industri pengolahan di Kota Probolinggo didominasi oleh industri agro dan kimia (IAK) sebanyak 802 unit sedangkan industri logam, mesin, tekstil dan aneka (ILMTA) sebanyak 138 unit dan industri alat transportasi, elektronika dan telematika (IATT) hanya sebanyak 15 unit. Peluang industri pengolahan telah menyumbangkan persentase yang cukup besar terhadap PDRB Kota Probolinggo. Sektor ini menyumbang sekitar 15,75 persen terhadap PDRB Kota Probolinggo ${ }^{(8)}$. Sehingga jika dikembangkan lebih lanjut lagi dengan industri kecil paska agro, akan semakin meningkatkan perekonomian Kota Probolinggo. Pertumbuhan sektor industri pengolahan di Kota Probolinggo semakin membaik seiring dengan membaiknya industri yang berorientasi ekspor. Seiring dengan pertumbuhan sektor industri kecil ini, secara langsung telah berkontribusi terhadap penurunan kualitas lingkungan sebagai dampak dari limbah yang dihasilkan.

Di sisi lain, sebagian besar masyarakat menganggap bahwa industri kecil adalah industri yang tidak berpotensi menimbulkan pencemaran terhadap lingkungan. Limbah dari industri skala kecil terkadang diabaikan karena besaran usahanya yang dianggap tidak terlalu signifikan, dan tidak terlalu berbahaya sehingga tidak perlu diatur secara seksama.Banyak industri kecil dan menengah yang memberikan dampak bervariasi pada lingkungan setempat.Studi juga menunjukkan bahwa sebagian besar polusi di daerah perkotaan merupakan hasil dari persebaraan emisi dari industri kecil dan menengah.

Pendekatan penegakan Hukum (law enforcement) kepada pelaku industri kecil dipandang kurang efektif dalam mengelola lingkungan.Oleh karena itu perlu diterapkan strategi pemahaman pengelolaan lingkungan yang lebih diarahkan pada upaya pencegahan pencemaran, yaitu mengurangi terbentuknya limbah. Kemudian usaha lain yang perlu dilakukan adalah memfasilitasi semua pihak untuk mengelola lingkungan secara hemat biaya serta memberikan keuntungan baik finansial maupun non finansial. Semua cara yang menuju pada penghematan bahan baku, energi dan air sedemikian rupa sehingga efisiensi naik dan limbah yang dihasilkan meenurun dikenal sebagai produksi bersih.

Dalam penelitian ini telah dilakukan penerapan produksi bersih mengambil kasus di PT Keramik Paolo, Jalan Brantas No. 46 A, Desa Pilang, Kademangan, Probolinggo.Pabrik Keramik Paolo memproduksi barang keramik seni, seperti pot bunga, vas bunga, roster dinding, tempat sabun keramik dan tea set berwarna.Jangkauan pemasaran adalah pasar luar dan dalam negeri. Dalam proses produksinya keramik Paolo mempunyai tungku shuttle sebanyak 6 unit dan dioperasikan oleh puluhan karyawan. Bahan baku utama yang digunakan dalam industri ini adalah feldspar dengan beberapa bahan pendukung lainnya, seperti air, cat, tanah liat (clay), dan lain sebagainya.

\subsection{Tujuan}

Tujuan penelitian ini adalah untuk mengidentifikasi jenis dan melakukan upaya penangananNon Produk Output (NPO)yang dihasilkan pada industri keramik PT. Keramik Paolo, memberikan rekomendasi untuk meningkatkan efisiensi produksi, menurunkan tingkat pencemaran serta menurunkan production cost perunit yang dihasilkan perusahaan.

\section{BAHAN DAN METODE}

\subsection{Bahan}

a. Bahan peningkatan capacity building

- Alat peraga

- ATK

b. Bahan

- $\quad$ Alat ukur watt meter

\subsection{Metode}

\section{a. Tahap-Tahap Penerapan Produksi Bersih}

Dalam penelitian ini, digunakan metode Material and Energy Flow Accounting-MEFA metode ini merupakan sebuah sistem akuntansi perusahaan berbasis alur keseimbangan massa yang diperkenalkan dalam Environmental Management Accounting (EMA $)^{(9)}$ dengan menekankan pada unsur pencegahan, pengurangan dan penghilangan limbah dari sumbernya yang merupakan unsur-unsur utama pelaksanaan produksi bersih. Pada pelaksanaan kegiatan dilakukan secara bertahap dan dibimbing oleh Tim Pendampingan sebagaimana digambarkan dalam Gambar 1. 


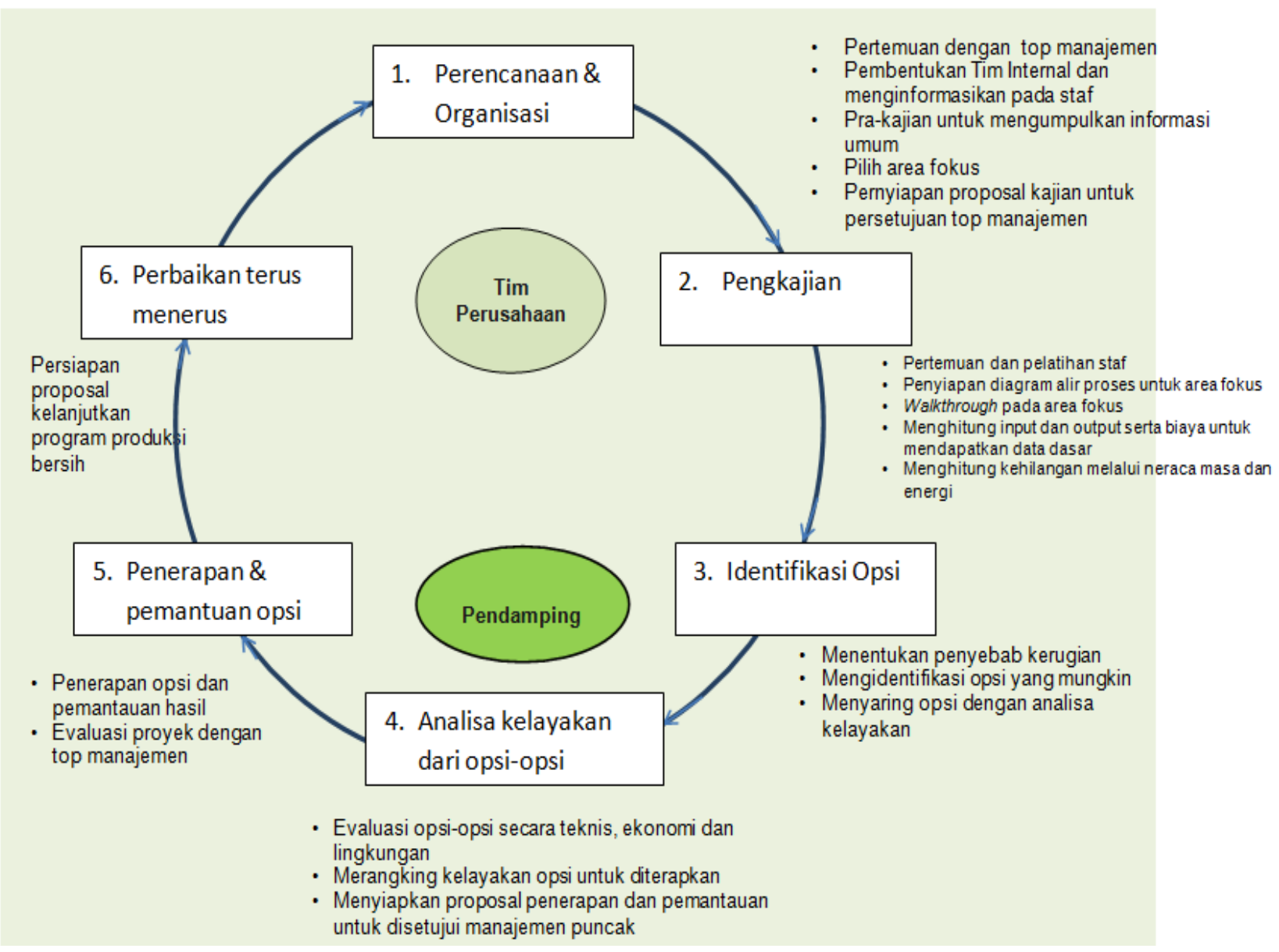

Gambar 1. Siklus dalam implementasi produksi bersih

Dari Gambar 1 diatas memperlihatkan langkahlangkah yang dilakukan oleh perusahaan bersama Tim Pendamping untuk membentuk tim produksi bersih dengan melakukan perencanaan dan membentuk tim ( tahap 1), selanjutnya melakukan pengkajian (tahap 2) yang diawali dengan pelatihan dan pengenalan produksi bersih, pengenalan Non Produk Output dan menghitung biaya-biaya. Pada tahap 3 mengidentikasi penyebab kerugian yang timbul, mengidentifikasi pilihan perbaikan yang dilanjutkan pada tahap 4 yaitu menganalisa pilihan perbaikkan terkait dengan kelayakan dan kesiapan sumberdaya yang tersedia pada perusahaan. Pada tahap 5 dilakukan penerapan opsi perbaikan dan dilanjutkan evaluasi hasil perbaikan hingga tahap perbaikan terus menerus (tahap 6) yang merupakan suatu siklus produksi bersih. Dalam penerapan ini, bertindak sebagai motor utama adalah tim internal perusahaan yang anggotanya dari unit produksi, unit lingkungan dan unit akuntansi yang nantinya akan menjadi winning team diperusahaan tersebut.
Pada kajian ini tahapan yang dilakukan baru sampai tahap 3, yaitu melakukan identifikasi pilihan pilihan yang mungkin dapat dikaji kelayakannya dari masing-masing pilihan tersebut.

\section{b. Analisa NPO (Non Product Output)}

Non Product Ouput (NPO) ${ }^{(10)}$ adalah keluaran yang bukan merupakan produk dan dapat dikategorikan jenis limbah yang masih bisa dipakai ulang, diminimisasi atau dilakukan pengolahan. Kesulitan utama yang dihadapi adalah memilih teknologi yang tepat untuk melakukan penghematan bahan baku, energi maupun air, apabila hasil neraca massa, neraca energi dan identifikasi yang dilakukan di sebuah unit menunjukkan adanya proses yang tidak atau kurang efisien (inefficiency) pemakaian bahan baku, energi maupun pemakaian air. Konsep NPO diperkenalkan untuk mempermudah para pelaku industri dalam menilai apakah proses yang dilakukannya sudah efisien atau belum. Secara 
lebih teknis Non Product Output adalah seluruh materi, energi dan air yang digunakan dalam proses produksi akan tetapi tidak berakhir (termasuk) dalam produk akhir yang diinginkan. NPO dapat juga dikatakan sebagai aktivitas yang tidak menghasilkan nilai tambah, dan akibatnya menghasilkan biaya yang tidak dikehendaki oleh perusahaan. Di samping itu, NPO yang berupa bahan pencemar tersebut seringkali mengarah pada suatu kondisi yang menimbulkan dampak negatif terhadap masyarakat dan lingkungan hidup.Total biaya terbentuknya NPO meliputi biaya besaran input yang menjadi NPO ditambah biaya pemprosesan NPO dan ditambah dengan biaya pembuangan $\mathrm{NPO}^{(12)}$

Dari data empiris nilai NPO pada suatu industri berkisar antara $10 \%$ dan $30 \%$ dari totral biaya produksi. Dengan kata lain bahwa potensi penghematan dengan melakukan penerapan prinsip produksi bersih mempunyai peluang yang cukup besar, dengan cara mengurangi besarnya NPO dimasing-masing proses produksinya. Untuk mendapatkan nilai NPO secara lebih jelas maka harus dilakukan dengan menyusun diagram alir bahan atau bagan alir produksi, dalam hal ini adalah bagan alir produksi keramik di PT. Keramik Paolo.

\section{HASIL DAN PEMBAHASAN}

\subsection{Analisa Diagram Alir Bahan}

PT.Paolo memproduksi barang keramik, berupa keramik seni, seperti pot bunga, vas bunga, roster dinding, tempat sabun keramik dan tea set berwarna.Jangkauan pemasarannya meliiputi pasar luar dan dalam negeri. Dalam proses produksinya keramik paolo mempunyai tungku shuttle sebanyak 6 unit dan didukung oleh puluhan karyawan.

Bahan baku utama yang digunakan dalam industri ini adalah feldspar dan beberapa bahan pendukung lainnya, seperti air, cat, tanah liat (clay), dan lain sebagainya. Adapun diagram alir proses produksi pada PT. Keramik Paolo dapat dilihat pada Gambar 2. di berikut ini.Berdasarkan diagram alir yang dimiliki oleh PT. Keramik Paolo, terlihat bahwa NPO yang terjadi berupa: emisi, limbah cair, limbah padat yang memerlukan perlakukan untuk diproses ulang, serta sedikit suara yang bising pada subproses penggilingan.

Bahan baku utamanya adalah tanah liat (feldspar) dan air, sedangkan bahan penunjangnya adalah listrik, clay, talc, pigment, gas alam, air, kertas karton dan isolasi.

Tenaga kerja tidak dimasukkan dalam diagram alir produksi dengan pertimbangan bahwa tenaga kerja merupakan faktor produksi yang melakukan proses produksi secara keseluruhan hingga menghasilkan produk yang diharapkan.

Pada Gambar 2 menunjukkan bahwa siklus produksi dimulai dari penggilingan bahan baku utama yang berupa feldspar (tanah liat) bersama air dan clay. Beberapa proses lainnya antara lain pengecekan laboratorium, pencetakan barang, pengeringan, penyempurnaan bentuk, penghalusan, pewarnaan, penyusunan, pembakaran, kualifikasi, pengepakan, dan pemasaran produk. Penggunaan energi selama proses produksi dibagi menjadi dua bagian, yaitu:

a. Energi listrik untuk penggunaan peralatan produksi dan pompa air; dan

b. Energi Gas Alam (Natural Gas) untuk pembakaran dalam tungku.

\subsection{Analisa NPO}

Hasil NPO yang berupa limbah cair belum diolah dengan baik karena PT. Keramik Paolo belum memiliki Instalasi Pengolahan Air Limbah (IPAL).Saat ini, PT Keramik Paolo hanya mengandalkan septictank untuk pengolahan limbah cair.Selain itu, limbah cair yang dihasilkan sering dibuang begitu saja atau disiram di halaman pabrik. Hal ini mengakibatkan tanah menjadi berwarna putih dan dapat menghilangkan unsur hara tanah.Seperti terlihat dalam diagram alir tersebut bahwa beberapa NPO dihasilkan oleh proses produksi keramik PT.Paolo yaitu antara lain limbah padat, limbah cair, uap panas, dan emisi. Limbah padat berupa potongan keramik sehabis penggilingan dan dapat diproses ulang (digiling lagi) sebelum proses pewarnaan. Lebih jelasnya, jenis NPO yang dihasilkan dalam satu kali proses produksi di PT. Keramik Paolo dapat dilihat pada Tabel 1 di bawah ini. 


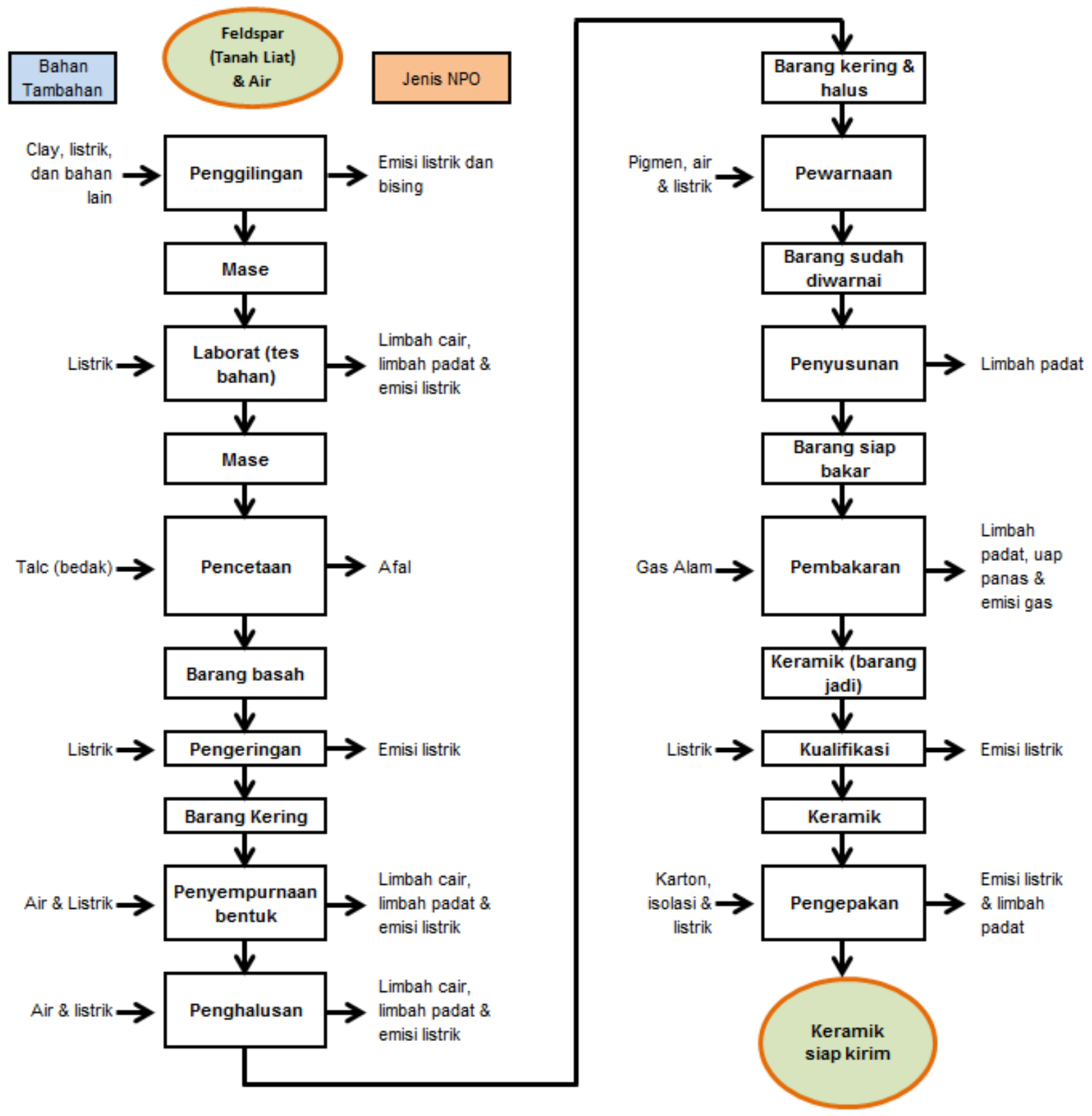

Gambar 2. Diagram alir proses produksi PT. Keramik Paolo

Pada saat pendampingan oleh Tim maka dilakukan diskusi dengan managemen mengenai penyusunan prioritasi penanganan NPO di industri PT. Keramik Paolo dan penyusunan rencana tindak atau aksi pengurangan NPO. Hasil diskusi memutuskanbahwa NPO yang terjadi di PT. Keramik Paolo ini harus dikurangi karena mempunyai dampak signifikan bagi perusahaan dari segi production cost.Jenis NPO yang dihasilkan berupa limbah padat yaitu patahan- patahan keramik, berupa limbah cair yaitu air bekas pencucian dan produksi, dan berupa emisi serta uap panas.

Gas emisi yang terbentuk dari sumber kegiatan penggilingan bahan baku utama, kegiatan tes bahan dan kegiatan pengeringan belum dilakukan upaya pengelolaan.Demikian pula gas emisi yang berasal dari kegiatan pengepakan. 
Tabel 1 Jenis NPO PT. Keramik Paolo

\begin{tabular}{|c|c|c|c|}
\hline No. & NPO & Sumber & Jumlah (per Hari) \\
\hline 1 & Emisi & Listrik dari penggilingan bahan & $\dot{z}^{*}$ \\
\hline 2 & Emisi & Listrik dari tes bahan & * \\
\hline 3 & Emisi & Listrik dari pengeringan & * \\
\hline \multirow[t]{2}{*}{4} & Limbah cair & Proses penyempurnaan bentuk & $\begin{array}{l}\text { Keseluruhan limbah cair sebanyak } \\
3000 \text { liter }\end{array}$ \\
\hline & Emisi & $\begin{array}{l}\text { Listrik dari penyempurnaan } \\
\text { bentuk }\end{array}$ & * \\
\hline \multirow[t]{2}{*}{5} & Limbah cair & Proses penghalusan & Lihat poin no. 4 \\
\hline & Emisi & Listrik dari proses penghalusan & * \\
\hline \multirow[t]{3}{*}{6} & Limbah cair & Proses pewarnaan & Lihat poin no. 4 \\
\hline & Limbah padat & Proses pewarnaan & $\begin{array}{l}\text { Keseluruhan limbah padat sebanyak } \\
20 \mathrm{~kg}\end{array}$ \\
\hline & Emisi & Listrik dari pewarnaan & * \\
\hline 7 & Limbah padat & Proses penyusunan & Lihat poin no. 6 \\
\hline \multirow[t]{3}{*}{8} & $\begin{array}{l}\text { Produk tidak } \\
\text { sesuai }\end{array}$ & $\begin{array}{l}\text { Proses pembakaran } \\
\text { (pengovenan) }\end{array}$ & Lihat poin no. 6 \\
\hline & Emisi & NG proses pembakaran & * \\
\hline & Uap Panas & NG proses pembakaran & * \\
\hline 9 & Emisi & Listrik kualifikasi barang & * \\
\hline \multirow[t]{2}{*}{10} & Limbah padat & Proses pengepakan & Lihat poin no. 6 \\
\hline & Emisi & Listrik proses pengepakan & \\
\hline
\end{tabular}

Sumber : Hasil Survei dan Pelaksanaan Workshop II, 2015.

\section{- Besarannya belum diketahui secara pasti}

Limbah cair yang dihasilkan dari kegiatan proses penyempurnaan bentuk, penghalusan dan pewarnaan dengan perkiraan jumlahnya sekitar 3.000 liter perhari telah dilakukan pengolahan sebagian dengan memasukkannya ke dalam septictank sedangkan sebagian lagi dibuang ketempat lain atau disiramkan ke halaman pabrik. Limbah padat yang bersumber dari proses pewarnaan yang besaranya sekitar $20 \mathrm{~kg}$ penanganannya dengan dibuang sebagai tanah urug. Demikian pula limbah padat yang bersumber dari kegiatan penyusunan dan produk keramik yang tidak sesuai spesifikasi pabrik yang berasal dari proses pembakaran (oven) dan dari proses pengepakaan atau pengemasan.

Gas emisi dari proses pembakaran meenggunakan bahan bakar gas alam belum ada upaya pengelolaan. Akan tetapi uap panas dari proses pembakaran ini sudah dimanfaatkan yaitu untuk pengeringan material atau bahan yang masih basah sehingga proses pengeringan tidak selalu tergantung pada panas matahari, terutama pada musim penghujan.

\section{KESIMPULAN}

Penerapan produksi bersih pada industri keramik PT. Keramik Paolo telah dapat memberikan penilaian dan gambaran sejauh mana pemborosan bahan baku, energi dan air serta bagaimana jenis dan jumlah limbah yang perlu dilakukan pengelolaan. Semua ukuranukuran tersebut dicerminkan dari besaran NPO yang dihasilkan.Melalui pendekatan NPO tersebut maka dapat dilakukan langkah-langkah perbaikan untuk mengurangi terbentuknya NPO.Upaya perbaikan harus dilakukan secara terus menerus sesuai dengan ketersedian sumberdaya yang dimiliki oleh perusahaan. Potensi penerapan produksi bersih pada industri keramik di PT.Keramik Paolo Kota Probolinggo cukuplah besar, mengingat industri keramik menggunakan energi yang sangat intensif (bersifat energy intensive), sehingga upaya penghematan konsumsi energi akan berdampak langsung pada penurunan biaya produksinya. Potensi penghematan biaya produksi keramik jika saransaran efisiensi dilaksanakan diperkirakan antara $10 \%$ dan $30 \%$ dari biaya produksi. 


\section{PERSANTUNAN}

Ucapan terima kasih disampaikan kepada Setiorini Sayekti, SKM, M.Si, dari Badan Lingkungan Hidup Kota Probolinggo yang telah memprakarsai kegiatan penelitian, serta Drh Wage Komarawidjaja MSi dari Pusat Teknologi Lingkungan, BPPT yang telah membantu penyusunan Karya Tulis IImiah

\section{DAFTAR PUSTAKA}

1. Chay Asdak, (2012), Kajian Lingkungan Hidup Strategis: Jalan Menuju Pembangunan Berkelanjutan, Gadjah Mada University Press, Yogyakarta

2. Anas M. Fauzi, Ainy Rahmawakhida, dan Yaoi Hidetoshi, (2008), Kajian Strategi Produksi Bersih di Industri Kecil Tapioka: Kasus Kelurahan Ciluar, Kecamatan Bogor Utara, Jurnal. Teknologi Industri Pertanian. Vol. 18(2), 60-65

3. Tentang Perlindungan dan Pengelolaan Lingkungan Hidup.

4. Schaltegger, S., (1980), Concept of EcoEfficiency University of Lueneburg,Germany.

5. Ariyanti, M., P. Purwanto, S. Suherman, (2014), Analisis Penerapan Produksi Bersih Menuju Industri Nata de coco Ramah Lingkungan, Jurnal Riset Teknologi Pencegahan Pencemaran Industri Vol. 5, No. 2, (45-50) .

6. Widodo, L. dan Wiharja, (2008), Peningkatan Efisiensi Perusahaan Melalaui Konsep Non Produk Output (NPO) Sebagai
Bagian Internalisasi, Jurnal Teknologi Lingkungan Edisi Khusus, Juli 2008, Pusat Teknologi Lingkungan BPPT.

7. Puspita Dewi W., (2016), Pengukuran Efisiensi Dengan Metode Sustainability Management Accounting Untuk UKM: Studi Kasus UKM Batik, Jurnal Energi, Vol. 6 No.1. Universitas Panca Marga.

8. (2015), Kota Probolinggo dalam Angka, Badan Pusat Statistik Kota Probolinggo Tahun 2015.

9. Puspita, D.W., ( 2016), Pengukuran Efisiensi Dengan Metode Sustainability Management Accounting Untuk UKM: Studi Kasus UKM Batik, Jurnal Energi, Vol. 6 No.1 Universitas Panca Marga,

10. Lieke Riadi, (2011), Analisis Non Product Output Dalam Rangka Penerapan Produksi Bersih di Berbagai Industri, Prosiding Seminar Nasional Perkembangan Riset dan Teknologi di Bidang Industri ke-17 Yogyakarta.

11. Jasch C., (2009), Environmental and Material Flow Cost Accounting Principles and Procedures, Springer, Austria.

12. Joko Susilo, (2016), Identifikasi Jenis dan Persentase Biaya Non Product Output (NPO), Efisiensi Produksi Melalui Penerapan Eko Efisiensi Pada Produksi Tahu Tradisional di Desa Banyuraden, Kecamatan Gamping Kabupaten Sleman, Jurnal Teknologi Kesehatan Volume 12 No 2 